Fit

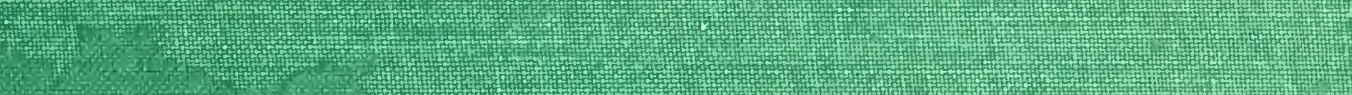
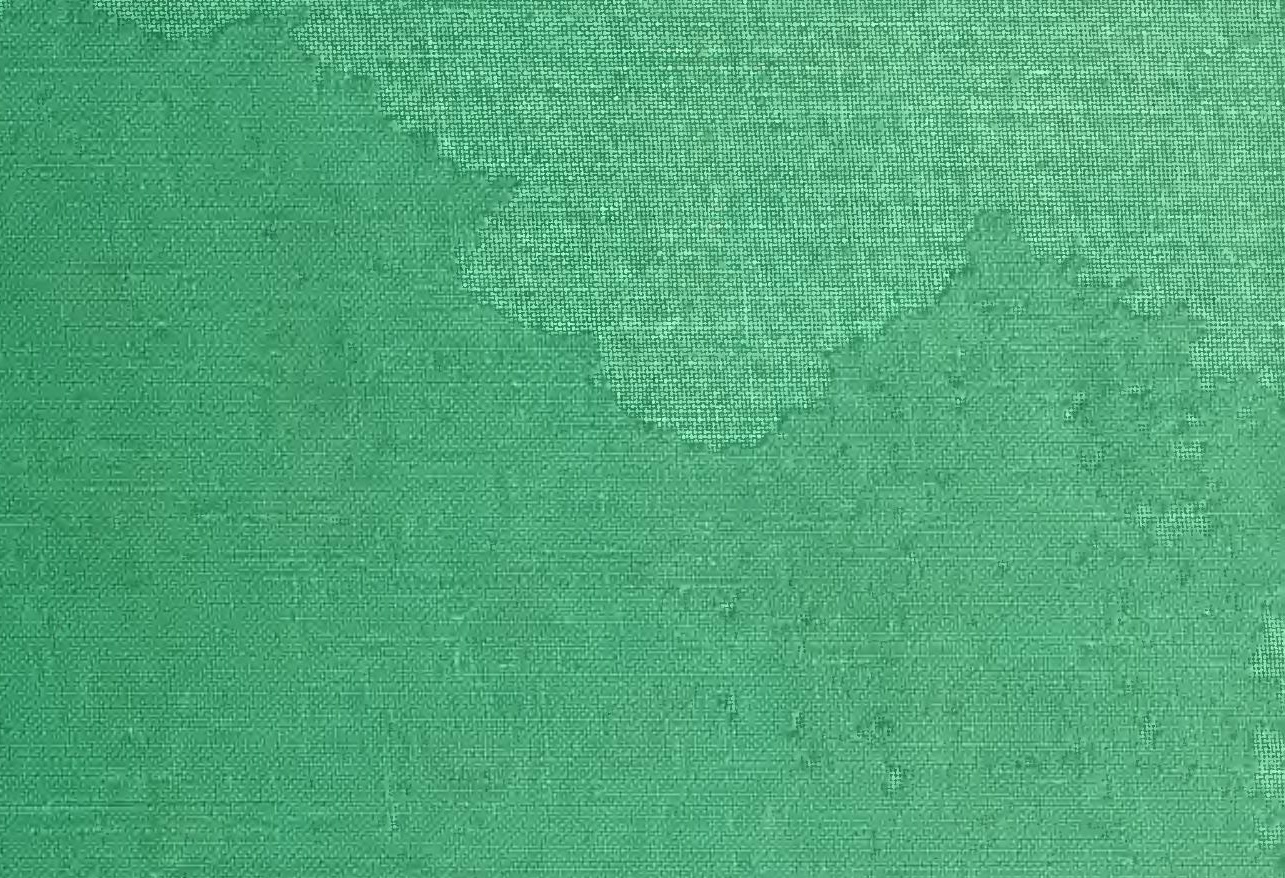

(1) 







\section{THE TRUTH ABOUT}

\section{THE BOLL WEEVIL}

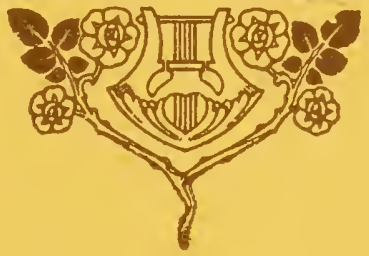

Complimente of

THE FIRST NATIONAL BANK GREENVILLE。 MISSISSIPPI 



\section{THE TRUTH ABOUT}

\section{THE BOLL WEEVIL}

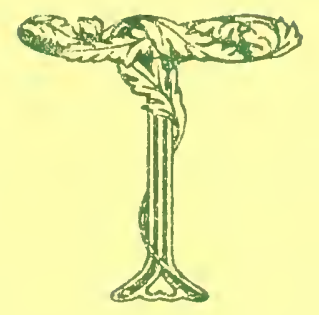

Being some observations on cotton growing under Boll Weevil conditions in certain areas of Louisiana, Texas and Mississippi.

By

ALFRED H. STONE and JULIAN H. FORT

Dunloith, Mississippi.

1910 


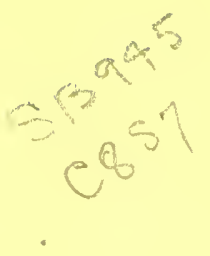

COPYAIGHT IOII

FIRSI NATIONAL BANK

GREENVILLE, MISSISSIPPI

(C) $\mathrm{Cl} A 280401$ 


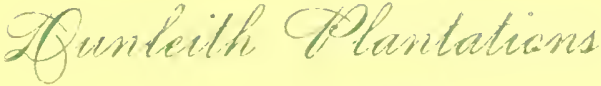

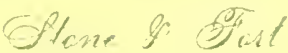 \\ OWNERS AND OPERATOFS}

Dunleith, Oflois. December 16, 1910.

Mr. W. H. Negus,

Prest. First Natl. Bank.

Greenville, Miss.

Dear Sir:-

Recalling the request made of us that your bank be given an opportunity of making public a report of our recent investigations into agricultural conditions in certain weevil infested areas of Louisiana, Texas and Mississippi, we herewith enclose a statement of our observations and conclusions. If this report contains anything of value to our immediate territory we shall be glad to have the cooperation of the First National Bank in bringing it to the attention of all those whose interests identify them with the problem of growing cotton under boll weevil conditions. Very truly yours,

(Signed) STONE \& FORT 


\section{PREFATORY NOTE}

The report which we are here permitted to present to the public does not demand a formal introduction. Nor is it necessary to say anything in behalf of its authors to those by whom they are known. For the benefit of those who may not be personally acquainted with them, we may say that in our judgment no such investigation as is hercin reported has ever been undertaken by anyone more competent both to get at the truth and to state it. Messrs. Stone $\otimes$ Fort combine the practical experience of seventeen years of cotton planting on a large scale with a wide familiarity with general economic conditions in the cotton beit. To these qualifications they add a thorough knowledge of the government and state literature on the subject of the boll weevil. We offer this report of their investigations with the confident belief that it will be found to contain much thorough and practical information that will be of value to both planters and business men in the territory through which we shall distribute it.

In our own behalf we may explain that our only purpose in bringing their report to public attention is to serve the business and agricultural interests of this section. It has been our belief that much of the financial distress which has overtaken communities on the appearance of the boll weevil might in our case be avoided by proper preparation and conservative management. A knowledge of the experiences of other sections, of their failures and successes, is absolutely essential to the safeguarding of our own interests in the face of the approaching boll weevil situation. Therefore, when we learned of the investigation contemplated by Messrs. Stone $\&$ Fort, it seemed to us that we could renoier a public service by securing permission to publish their observations and conclusions.

In submitting their report we bespeak for it the consideration which we think it deserves.

THE FIRST NATIONAL BANK

Greenville, Mississippi 


\section{PRELIMINARY OBSERVATIONS.}

Probably no other insect pest in the history of any of the American staple crops has provoked the same amount of discussion as has the Mexican boll weevil since it crossed the Rio Grande river, about the year 1892. In 1909 Hunter estimated the infested area to be approximately 225,000 square miles, including portions of Texas, Oklahoma, Louisiana, Arkansas and Mississippi. Since this estimate was made the weevil has completed its movement across southern Mississippi, and has invaded Alabama. When the extent of the affected territory is considered, it is apparcint that it must neccssarily embrace a very great variety of physical and economic conditions, which in turn may readily account for the confusing, contradictory and hence frequently misleading character of the discussions which have followed the path of the weevil across the cotton belt. There is no hard and fast rule for planting, cultivating and handling a crop which is grown from the Mexican border to the North Carolina uplands, and from Southern Missouri to the Gulf of Mexico. Neither is there any fixed standard for measuring the effect through such an area of the vicissitudes of climate or the damage from insect pests. Yet, in trying to summarize the impressions of three years' study of boll weevil literature the one thing which stands out most distinctly in our minds is an apparent attempt to apply to the whole cotton growing area the contradictory experiences of a variety of widcly different localities. We are told that the boll weevil will work havoc throughout the entire cotton belt; that its advent means the end of staple cotton growing; that its spread will finally break up the plantation system of raising cotton on a large scale, and bring everything to the level of the small farm, with cotton as a "surplus crop." Yet none of these things can be established in advance of the fact of its actual accomplishment, and most of the predictions are still no more than predictions.

\section{THE BOLL WEEVIL A LOCAL PROBLEM.}

We, of course, realize that certain generalizations may be safely made of boll weevil habits and operations, and we appreciate the value of many of the scientific bulletins, dealing with the pest, issued by the 
National Department of Agriculture, and by various State departments. But we are none the less of the conviction that, after all, the boll weevil presents a variety of local problems, differing with local labor and economic conditions, and influenced ty physical considerations of soil, rainfall, temperature, vegetation, drainage, etc., all peculiarly local in character. The only lessons of value to us, therefore, are such as may be drawn from the experiences of others in situations locally similar to ours. The success of a farmer on a Texan windswept prairie, working with wheel cultivators 50 acres of cotton to the man, offers us no legitimate ground of hope. It would be equally as foolish to become discouraged bccause of the failure of a cotton planter in the semi-tropical cane belt parishes of Louisiana.

In planning the investigation which we have just concluded, we were governed by the considerations which we have suggested. The problem which confronts the people of this county, and probably of the greater portion of the Delta as a whole, as it presents itself to us, is that of growing cotton profitably, notwithstanding the weevil, in what is known as an alluvial "swamp" country, as distinguished from a "hill" or "prairie" section, under the plantation system of labor and management, on a variety of soils ranging from stiff buckshot to sandy loam, with a rainfall average of 47 to 50 inches, with an average temperature of 64 degrees, at an altitude ranging around 126 feet above sea level, and between the $33 \mathrm{~d}$ and $34^{\text {th }}$ degrees of north latitude. In mapping our route we first studied the physical conditions of various boll weevil districts, and selected such as most nearly approximated those of the Delta. We then studied the effect of the weevil in these different areas, as far as disclosed in government crop reports, and as we could ascertain it through correspondence with planters, merchants and others. We selected also certain areas typical of physical and economic conditions entirely different from ours here, shat we might be able to draw intelligent comparisons between the two, and more accurately measure the force of local conditions in the general boll weevil problem. The sections which we visited embraced portions of the "swamp" regions of Southern or South Central Louis- 
iana, along the Mississippi, Atchafalaya and lower Red rivers, alluvial parishes in northwestern Louisiana, along the Red river, the "swamp" sections of eastern Louisiana, along the Mississippi, timbered counties in North and East Texas, and the Natchez district, along the Mississippi and south of the Big Black, in this State. We visited only such sections as had had from three to eiglit years of experience with the boll weevil. We adhered uniformly to the plan of making immediate notes and memoranda of all observations, interviews and figures, and of writing up each night a journal of the day's impressions and conclusions. In every instance, save one unimportant locality in Texas, we interviewed from three to eight persons. We endeavored to get at the truth of conditions at the time of the original appearance of the boll weevil, as well as at later dates, on down to the close of rgro. This involved an inquiry into such other factors, affecting the crop from year to year, as the panic created by the weevil's first appcarance, rainfall, droughts, etc., labor conditions and individral policy and management. We discussed conditions with planters, managers, and negro tenants, merchants, cotton factors, bankers and insurance men, and with various individuals casually met in hotels and on trains. Our trip occupied fifteen days, and we covered r,260 miles by rail and 340 miles through various interior parts of the country by team and automobile. We endeavored to get at the root of every situation which we investigated, and accepted as final no off-hand conclusions or unsupported statements. The trip was not a junket on our part, but was a serious business proposition, undertaken solely for our own guidance in framing a policy for our planting operations when the long threatened boll weevil invasion shall have become a reality.

\section{THE EXPERIENCES OF OTHERS.}

To give a detailed account of every step of our journey and set down the observations made at every point, would make this report unnecessarily voluminous. We shall confine ourselves to certain typical districts which offer opportunities for comparing and contrasting other situations and conditions with those here at home. We shall first discuss conditions furthest removed from ours, and then take up those having most in common with us. 


\section{THE NATCHEZ DISTRICT.}

It may seem somewhat singular to follow this statement of our plan of treatment, with a consideration of the only section of onr State which has been afflicted with the weevil for any length of time. In the order of our route of investigation, this territory was in fact the last we visited. But in the light of our cbservations we are satisfied that no other region which we studied exhibits a greater divergence from Delta conditions than the Southwest Mississippi riparian counties of which Adams is typical. This difference is due to a combination of both physical and economic causes.

In the first place, there is a striking absence of any similarity of plysical environment. Adams is a county of hills, gullies and ravines, with here and there a creek bottom broadened out into a few level acres. Occasionally we saw a farm of from 50 to 100 acres occupying what seemed to be an elevated plateau, but even here the land was seared and washed out of all semblance to an unbroken field. The soil has the reddish cast seemingly typical of all hill countries, with neither the richness nor texture of the same colored land in the Red river valley. It is worn and exhausted by well nigh a century of constant cultivation. A study of the vegetation gave constantly suggestive reminders of the semi-tropical region which we had visited in Louisiana. Magnolias of magnificent proportions are scattered through the woods. Pints are everywhere in evidence, and Spanish moss is uncomfortably thrifty and abundant.

In its economic aspects the differences between Adams county and the Delta are as strongly emphasized as in its physical. A very great proportion of the total arable land of the county is owned in the City of Natchez. From what we could learn we judged that practically all of it was furnished from that place. It was rented in small tracts, ranging from twenty to two hundred acres, to tenants, who depended upon local merchants for supplies. The land owner had nothing to do with either his land or his tenant, further than to collect his rent. There were thus three parties in interest, the landlord, the merchant and the tenant, with no co-operation between them. Such a thing as 
a plantation, as we understand the term and the organization here, does not exist in the county. In fact, we do not see how it could ever have existed, under the broken and disjointed soil conditions which characterized all the land we saw. The nearest approach even to the plantation system of furnishing, was where a merchant owned a lot of land and supplied his own tenants. Even in these cases, the land was usually in a number of detached tracts, without any element of cohesiveness among the scattered tenants. The appearance of the boll weevil created the same panic and demoralization which we had investigated further West and South. But there was this radical difference: Not only was there no organized effort to allay fright, quiet lahor and instil confidence, but so far as we could learn, there was not one single planter or plantation to stand up and make a fight to demonstrate what might be done. Wherever we found the plantation system. with the single exception of the cane parishes of the Atchafolaya and Red rivers, we invariably found individual instances of planters of means or credit who, from the very first appearance of the weevil down to the present time, had made cotton and had been able successfully to readjust their operations to the new conditions. These men created confidence in their neighbors, furnished object lessons of the folly of demoralization and marked out the way for the re-establishment of the business of cotton growing upon a sounder and more enduring basis than before.

Instead of this, there was in the Natchez district situation apparently but a single end and purpose. This was the saving by the advancing merchant of as much as possible for himself, out of what seems to have been considered from the very beginning an inevitable and hopeless economic wreck.

The merchant determined to realize what he could out of the meagre personal property which represented the only remaining asset of the negro tenant. The land owner, unaccustomed either to supplying his tenants or to handling his land himself, and wholly without confidence in the future, apparently made no effort to save the labor to the land by stepping in between his tenant and the arvancing mer- 
chant. The merchant who combined landholding with an advancing business must necessarily have shared the general panic, just as his tenants shared the general demoralization of labor. It was at this juncture that the Delta planter appeared upon the scene, and added to the existing confusion by making possible an exodus for which the negro was already prepared, and which only needed financing to become an accomplished fact. We found no evilence that the planter from this section had ever stirred up the labor situation. or in any case persuaded a negro to leave. Nor do we see how any blame can be justly attached to his actions. The country roads leading into Natchez were filled with negroes, wagons and mules; the streets of the town were filled with puzzled negroes, upset. disturbed and bewildered. They knew nothing except that their merchants would carry them no longer, that they could not carry themselves. and that they had been called upon to pay what they owed or surrender what they had mortgaged. Every available pen in the city was filled with horses and mules. The planter from the Delta needed the labor. and the latter was eager to go. The planter paid the merchant an agreed price for the negro's account, loaded him and his family and household plunder on a boat or car, and brought the entire ontfit home. Hundreds of negroes and carloads of live stock and personal property were thus removed from Adams and adjoining counties. Thousands of dollars of Delta money were put into circulation there in the process of exchange, but when the final account was closed, the net result to those counties was, on the one hand a group of fairly well satisfied city merchants, and on the other a disorganized country, stripped of labor, farming implenents and stock, empty houses on tenantless land -a picture of desolation for a counterpart to which memory must return to the devastation of the Civil War.

If any man imagines this description to be uverdrawn. let him 7raverse that country and talk to its people to-day-even now after wasted fields have become a fixed feature of the landscape and the thought of dwindling crops a fixed habit of the mind. In 1906, Adams county grew 23,836 bales of cotton; 20,455 in 1907; 14,155 in 1908: 
1,700 in 1909 ; in 1910 conservative estimates place the crop at less than 900 bales. Under normal conditions there were 42 gins in operation. In 1909 there were sixteen. We are told that this year there were only eight.

In face of the wreck which this recital tells, it is idle to speculate upon what might have been. It is almost as profitless as it would be ungracious even to attempt to apportion the blame for what is. We shall only say that whether the ruin of this historic region as a cotton country lies all at the door of the boll weevil, or is due to economic and physical conditions combined with ensuing panic-whatever the cause-the destruction is complete. Next to sympathy for a distressed and an harassed people, may come congratulations to ourselves that in not one single feature did their normal situation resemble ours. We have nothing to fear from their experience, in so far as natural conditions are concerned. In so far as their demoralization affected the result, we may consider their case with infinite profit.

\section{TEXAS.}

As the weevil was for a number of years confined to Texas, it was natural that the rest of the cotton belt should become accustomed to the idea of looking to that State for instruction in the effort to handle the situation created by the appearance of the pest elsewhere. But we have not much to learn from Texas, for the reason that there is no considerable weevil infested area in that State where we may find conditions to parallel our own. Economic conditions in some portions of the Brazos river region, the plantation districts, are somewhat analogous to ours, but we are 200 miles north of even such counties as Robertson, and 300 miles further east. We are too far apart for safe comparisons and conclusions, but we may remark in passing that the advantage of location is all with us. We may learn from Harrison county that cotton can be safely and profitably grown in a heavily wooded country, with a heavy rainfall, but Harrison is in no sense an alluvial county such as ours. 
One lesson we may learn, however, from any portion of Texas, and that is the senselessness of becoming panic stricken when the weevil appears. Even in the comnties of Bowie, Red River and Lamar, practically in our latitude, there was repeated the same story of demoralization which could be told of districts hundreds of miles further south. But in cvery instance there followed a readjustment and recuperation which merely emphasized the folly of the original panic. An analysis of the crops of any or all of these counties shows that they have at times suffered as mucl from the vicissitudes of weather, before the appearance of the weevil, as they have subsequently from the weevil itself. In I905, Red River county, with no weevils, made 0.408 bales. After the weevil appeared it made, in 1907 , 19,618 bales; in 1008, I7.766 bales; in I909, 19.722 bales. And this with a greatly reducel acreage. In I905, a year of excessive rains, Lamar connty, with no weevils, made only 32,423 bales. IVith normal seasons, hut with weevils all over the county, and a mucli reduced acreage, it made $43,22+4$ bales in 10,08 and 44,612 bales in 19o9. Harrison county is on the castern borler of Texas, and in about the same latitude as Warren in this State. 1000 was a hanner cotton year in Harrison county, and 18, I $_{3}$ I bales were raised. The boll weevil struck them in 1907 and the crop fell to 7,883 bales. The county was spotted with abandoned fields and a state of panic prevailed eciual to that produced by a pestilence. With a return of sanity and a return to work, the county produced 17,394 bales in 1909. Thus with a thorough infestation of weevils and a reduced acreage. the crop of 1909 was only 737 bales less than that of 1906. In 1905 . With a wet year, but with a fill acreage and no weevils, the crop was II, I55 bales, or 0.239 bales less than in the weevil year of 1909. In Kaufman county the largest crop in six years, 60,608 bales, was made in Igos. Contrast this with the 29,004 bales made in 1905. a wet year, but with no weevils.

We talked with a number of people in Bowic, Red River. Lamar, Kaufman and llarrison counties. We found an entire absence of fear of the weevil, and, instead, a universal feeling of confidence and 
security. Both farming and mercantile operations are more conservatively conducted than before the appearance of the pest. Ireal estate values are as high as before and are on a much sonnder basis. But this is not a "swamp" country. Cotton is grown in the main under a "farming" instead of a "planting" system. And most of the labor we saw was white. We would, however, again emphasize the statement that in the history of the effect of the wecril wherever it has appeared, we may learn one lesson of infinite value even from North and East Texas. This is that whether the conntry be prairie, alluvial or hill, disaster has followed panic, and prosperity has come with a return of sanity and such readjustment of farming and business methods as prudence and common sense have suggested. The bald, unanswerable fact is patent throughout the entire cotton belt of Texas-that cotton is still being yrown, that prosperity is on the increase, and that the boll weevil has ceased to be a cause of alarm or even a topic of conversation.

\section{LOUISIANA.}

The parishes of Louisiana which we shall consider here are Caddo and Madison and the gromp composed of Rapides, Avoyelles and Pointe Coupee. Shreveport, in Caddo, is on Red River, a little north of an east and west line through Vicksburg, and about 136 miles west of the latter place. The portion of Caddo Parish which wc visited was the territory adjacent to Shreveport, and occupying to it the same business relations as exist between Greenville and the outlying country. This is an alluvial region with a soil somewhat similar to much of ours. except for the reddish color of the river deposits of which it is formed. Shreveport has been for years the center of a banking. factorage and general business, hased mainly upun cotton, and conducted similarly to ours in the Delta. The weevil struck this part of the parish in the summer of 1906 , and created the usual panic and demoralization. Planters' credits were almost universally curtailed, and some could not secure advances at all. Labor shared the invariable tate of such situations. The negro either had 
his supplies cut off or suddenly reduced to a minimum meat and bread basis. His conduct was shaped by that of the white man upon whom he depended for his daily living. Where the planter became demoralized and was ready to give up without a struggle, the negro naturally either ran or worked in a half-hearted way. Where the planter and his factor or banker got together and agreed to see the thing through to a finish, there was little if any difficulty in instilling confidence into the negro and handling him so as to get satisfactory results. We found no instance here of failure to make a profitable crop where there existed co-operation between the planter, the factor and the labor, coupled with proper management. On the contrary, we found no case in which failure had not followed demoralization and disorganization.

Caddo has furnished the classic example of the destructive capacity of the weevil. Since 1908 we have heard a hundred times of a plantation which in 1907 produced 1,700 bales and the following year made only 210. We had not, however, heard of the adjacent place, which has made half a bale or more to the acre ever since the weevil came, and made it at a profit. The situation thus presented serves as a fair illustration of the numerous "mysteries" which follow in the wake of every visitation of the weevil. We were told on every hand of this man who failed where another succeeded; of fields which made half or three-quarters of a bale, or even a bale, to the acre, while just across a ditch or a fence the weevil wrought absolute destruction. Ordinary common sense suggests that there must be some tangible reason for such occurrences, but it was often difficult to get at the real explanation. We may as well say here as elsewhere that it is our belief that no other insect since the dawn of history, not excepting the Egyptian locust, has had to bear the burden piled by human nature upon the boll weevil. When he once appears all other causes of crop failure are forgotten. It is not even remembered that there were any short crops before. We visited very few places where we were not assured with the utmost gravity that "before the weevil came we always made a bale to the acre." The 
ravages of the arisy worm are forgotten; the boll worm is no longer mentioned; blight is not taken into account; boll rot is not thought of; shortages of labor and consequent overcropping of tenants are ignored; no attention is given the hundred and one things which always have been and always will be limiting factors in cotton produrtion-but everything is charged to the weevil. We have talked to men whose land, equipment and general surroundings did not seem to us to justify more than half a bale under the most favorable conditions, and been told that while they got only 250 to 300 pounds of lint now, they "used to make from 400 to 500 every year."

To return to the case in point. After two days of patient inquiry we stumbled upon the fact that the owner of this particular I,70o-bale place had repeatedly expressed the conviction that cotton could not be grown under boll weevil conditions; that he had made every effort to put his land into other crops; that he had put in 1,000 acres of alfalfa, and a lot of such truck as potatoes and peanuts; that after the weevil came he had treated his cotton practically as a side line; that he did not have sufficient labor to handle all his different efforts at diversification, and irequently took hands out of his cotton and put them into his other crops. His neighbor had put in some alfalfa and peanuts, but had stuck to cotton as his money crop and main reliance. and had made good at it.

Driving out to a plantation from Shreveport one day in an automobile, with the owner of the place, we passed several wagons loaded with household plunder. It was a negro family from the very plantation to which we were going. Our friend told us that he had paid this darkey a boll weevil balance this year of a little over $\$ 800$, but he had decided to "move"- because he did not like another negro in an adjoining house. This planter had seven other tenants to whom he had paid balances ranging from $\$ 350$ to $\$ 500$. His place contained I,000 acres, and before the weevil came he had planted 8 o acres of cotton and had a ten-year average of 500 bales. Since the weevil appeared he had reduced his cotton to 600 acres and had averaged about half a bale. His yield this year was 234 pounds per acre, but 
on further inquiry we found that he had "diversified" in 1909 by planting I 30 acres in sorglium - with results to the I9Io cotton crop on this land which can be appreciated by every planter who has ever followed sorghum with cotton. This reduced his plantation average heavily. We also found that on some cuts he had gathered this year from 400 to 500 pounds of lint per acre.

We were told by the head of one of the largest factorage and wholesale grocery houses in Shreveport that he was now selling at prices ranging from $\$ 45$ to $\$ 60$ per acre land which his louse could hardly more than give away the first year after the weevil appeared. And this land is being sold solely for cotton growing-not for trucking or diversifying. This gentleman assured us that his business was on a much more satisfactory basis than formerly, and that the boll weevil had been very far from an unmixed evil in his parish. The planter to whom we just have referred intends to return to practically an allcotton basis next year-planting only lis feedstuff. He is plowing up one-third of an I50-acre alfalfa field for cotton. Since the weevil struck him he has built a new cotton house at his gin, $84 \times 26$ feet, and he is preparing to increase its capacity by half. He could not find a purchaser for his plantation of 1,000 acres at any price in 1907 . He this year refused a cash offer of $\$ 50,000$ for it. And yet we are told by the owner of property side by side with his, and not differing from it in any particular whatever, that cotton could not be grown under boll weevil conditions. The planter of whom we speak owns an automobile and does not seem to lead a particularly strenuous life-but his home is on his property, and that is where he lives. The other gentleman resides in the city of Shreveport.

We looked into conditions in Webster parish, merely to compare a Louisiana "farming" proposition with "planting" operations. We saw no negro labor in the portion of Webster which we visited. They were all white farmers, owning from 40 acres to 250 . They could not run when the weevil struck their section in 1906 and 1907, and apparently had no desire to do so. We found here another illustration of the necessity of going below the surface to get at the truth of a 
boll weevil situation. We ran across an old farmer who owned some 260 acres of land and had three sons farming near his place. He told us that the boll weevil was an awful pest; that he used to make a bale to the acre every year, on hill land, with fertilizer, but now he couldn't count on more than a half. While we were talking to the old gentleman, a neighbor canic up and made some remark about a fine crop he had heard of the old man's son having made this year. He admitted that his boy Bill had gotten eight big ties from eleven acres. We pressed him for some explanation of the difference between his son's yield and his own-he having clained that his had been cut by the weevil this year to about a third of a bale. Ile hesitated a moment, then said: "Well, the truth is that Bill stuck to his crop from start to finish, and as for me and the other boys, I reckon we done just a little too damn much sawmillin'."

There is as much change of scenery, vegctation and general physical condition to be witnessed in following the valley of the Red River down from Shreveport to Alexandria as there is along the Mississippi from Cairo to the Gulf. The territory above Shreveport was before the Civii War one of the greatest cotton countries in the world, that to the south and sontheast of Alexandria was probably the greatest cane region in America. Both are alluvial, but there the similarity ends. The difierence of about 80 miles of latitude between the two so alters the factor of physical environment that, notwithstanding the boll weevil, the upper district is still a cotton country, with every prospect of regaining or surpassing its ante-bellum prosperity-while the lower bas been practically driven out of cotton growing and forced back into the economic position which it occupied sixty years ago, in its dependence upon cane as its staple crop. In the American history of the Mexican boll weevil there probably is nowhere else presented as striking a demonstration of the almost dominant part played by physical conditions in determining the potential destructive capacity of that insect as in the parishes of Rapides. Avoyelles, Pointe Coupee and St. Landry. To 
these might be added East and West Feliciana and East and West Baton Rouge, but the first four will answer our purpose. It might be asked why not include Wilkinson and Adams counties, in Mississippi, as having suffered practically as great damagre as the parishes mentioned in Louisiana. The most striking difference between the Mississippi and Louisiana groups is a difference of economic conditions and of farming methods and organization, and these we have already discussed. These Mississippi counties nay have suffered equally, but it was through a combination of both economic and physical causes. It seems clear to us, on the other hand, that the difficulties against which an unsuccessful fight was made in such parishes as Avoyelles and Pointe Coupee were not economic at all, but were almost wholly pliysical. With the planters in these parishes the boll weevil fight was in truth a struggle with nature herself, and nature, not the boll weevil, won. $\mathrm{WW}$ are not willing to say that with a similar plantation system the result would have been materially different in Adams and Wilkinson. There may be enough similarity of physical conditions between the two groups to have made the end the same there as in Avoyelles and Pointe Coupee. But we are avoiding every form of speculation in this effort to get at the root of the problem, and in the absence of such economic conditions and methods as obtained on the Louisiana side, it is manifestly safer not to say what might have happened under circumstances which did not in fact exist.

We left the railroad at Alexandria, on the Red River, and went by team and automobile through the Bayou De Glaises and Atchafalaya River country, some ninety odd niles. We traversed the parishes of Rapides, Avoyelles and Pointe Coupee, and struck the railroad again at a point within a few miles of the Mississippi. On every mile of the trip we rcalized that we were at last in a semitropical country. These parishes are in fact along the upper edge of tropical Louisiana. Spanish moss covered every tree from top to bottom, and reached from the lower limbs to the ground. At a little distance the density of its growth gave the timber along banks of 
sloughs and bayous the appearance of gray, unbroken, impenetrable walls. Spanish daggers and palmettoes grew to tropical dimensions and the woods were filled with evergreen trees and shrubs. Save for an occasional stretch of what was locally known as prairie land, the landscape everywhere bore the typical swamp country appearance, with every tropical feature emphasized and brought into relief. Such cotton as we saw was planted on beds as high as could be thrown up with an especially adapted "Lone Star" mouldboard, and would average probably twice as high as any we had seen elsewhere.

Before the Civil War, as we have already stated, this was a great cane country, and little if any cotton was planted. We passed numerous reminders of its ancient glory, in the shape of massive brick sugar houses, here and there crumbled into ruin, but occasionally still sufficient to serve for stables or other uses. The sugar industry was destroyed with the destruction of its sugar houses by the Federal army. The capital required for its re-establishment was too great for an impoverished country, and after I865 the people turned to cotton as the best available substitute crop. It is said that this section marks the northern limit of dependable cane production. The stubble is never winter killed, and does not require the covering of a single furrow for its protection. The boll weevil has now apparently placed it below the southern limit of profitable cotton growing as a plantation staple crop. We say as a staple crop advisedly, for even here cotton is still grown. We rode for miles through a country of thrifty French farmers, all of whom were making some cotton. But it is becoming more and more a side line, even with them.

We spent a night with one of the most successful planters in all this territory, a man of education and means, noted for his energy and business capacity. In 1906 he grew 1,500 bales of cotton on 1,800 acres. In 1907 he grew 1,400 bales. The weevil appeared in the late summer of that year. In 1908 he got 198 bales from the same acreage as in 1906 and 1907 . He did not give $11 p$ in disgust, but turned at once to the ante bellum crop, and will easily occupy the same rank as a cane grower that he once held as a cotton planter. This gentleman furnished us the one solitary example which we found in all vur journey of an absolute failure to grow cotton profitably under the plantation system, despite the weevil, where the planter lived on his 
place, made the necessary changes of method, seed, etc., kept his labor and maintained his plantation organization intact. In so far as. we conld ascertain, nothing was neglected which should have been done. But the cause of failure was written on the wlole face of the landscape. One gentleman remarked to is: "They tell us to clean up, burn stalks and destroy all places of hibernation, when there is sufficient moss on any tree on the bank of that bayou to winter enough weevils to destroy all the criton in the parish." And they have to contend with another thing which we did not discover to exist elsewhere. The rainfall is enly eight to ten inches rreater there than with us, but during the growing season the dew moisture is so heavy as frequently to keep the ground damp for days at a time. It is thus impossible, even with widened rows, to maintain anything like a dust mulch, while the moist, warn earth facilitates the hatching of weevils. After all that we had seen of the country, we were not surprised at being told that the excellent oranges served at breakfast came from our host's own trees.

The ignorance of people in one section of a State, of conditions which confront their neighlurs in other counties, was frequently illustrated in our boll weevil conversations in Louisiana and Mississippi In southwest Mississippi we were assured by intelligent men that cotton could not be successfully grown anywhere in the State, simply because their section had made a failure of it. On the other hand, in discussing Avoyelles and Rapides parishes with parties in De Soto. we were told that the only reason cotton was nut profitably grown on the lower Red River was that the people there had not made the right sort of fight against the weevil. Now, De Suto is in about the same latitude as Warren County, and is about $₫ 20$ miles northwest of Avoyelles. It is a Red River parish, on the western edge of the State. After suffering a drop from 17,214 bales in 1906 to 6,343 bales in 1907 , it soon regained its boll weevil losses and in $r 909$ produced 14, I4 I bales. From 4I,050 bales in 1906, Rapides has steadily fallen to 4,685 bales in 1909 . Avoyelles fell from 48,003 in 1006 to 8,164 in rgo9. St. Landry fell from 68,923 to 17,002 , and Pointe Coupee from 50,516 to 3,377 . The combined yield of these parishes in I909 was 7,822 bales less than the single yield of the smallest of the fout 
in 1900. The total yield of the group represented a fall from 208,492 bales in 1906 to 33,228 bales in 1909 . If we contrast this with the recovery in De Soto, just mentioned above, and recognize the fact that the people on the lower Red are just as intelligent, just as capable and just as determined as those further up stream, it is apparent, unless we believe in material miracles, that there must exist some definite, tangible, fundamental cause for the disastrous difference between the results of their efforts. It was the object of our investigations to ascertain this cause, as it is of this report to point it out. To further indicate the controlling force of climatic conditions and physical environment, before leaving this group we may give the experience of a gentleman in Pointe Coupce. After turning his entire place into cane and corn he persisted in experimenting with cotton on a small scale, to test the efficacy of intensive methods. He planted ten acres in cotton in 1909 , cultivated it by wages, expended $\$ 385$ on it, and gathered one bale weighing 490 pounds.

The object which most interested us at the little station in Pointe Coupee parish where we took the train going north, was an oil mill, magnificently constructed and equipped. It was a pathetic spectacle, "as idle as a painted ship upon a painted ocean." In two years not a fire had been kindled under its boilers. The boll weevil had put it out of business. The first thing which greeted us as we left the train in Madison parish was the hoarse whistle of a gin, and we saw more cotton piled upon its yards than we had seen aitogether in five parishes further south. We were at last back in a cotton countryeven though one infested with weevils since 1907. We saw no magnolias growing wild in these woods; no pines nor evergreens: and while here and there we noticed a considerable sprinkling of Spanish moss, the oranges we ate were imported.

Madison parish, in our judgment, offers the best field now available for the study of cotton growing under weevil conditions, trum the viewpoint of the Delta planter. It has had the weevil since the late summer of 1907 , and has thus made three crops under its handicap. It has a soil almost identical with that of Washington county, both in variety and type. Its timber and undergrowth are so similar to ours as not to be distinguishable. It has precisely the 
same system of water courses as ours-the same character of bayous, creeks and lakes. If anything, on the whole our natural drainage is the better. While the growth of Spanish moss is insignificant, as compared with that in such parishes as Rapides and Avoyelles, it is still many times greater than ours. In fact we have practically no moss at all, except upon the banks of a few lakes in one or two portions of the county. Cotton is grown under a plantation and labor system in every essential respect identical with ours. The only difference of location is that Madison parish lies on the west bank of the Mississippi and Washington county on the east. The advantage of latitude is again with us, the county seat of Madison parish, Tallulain, on the V., S. \& P. R. R., being about seventy miles south of (ircenville and a few miles further west.

The contrast between the results of a level-headed, sane determination to make cotton in spite of the weevil, and the effects of a panic-stricken policy, are not often brought into such striking juxtaposition as here. In a ride of some 140 miles through the parish, by team and automobile, we saw the two lines of action illustrated side by side. We saw abandoned property, with idle gins and empty cahins, immediately adjoining places which have made from half to three-quarters of a bale to the acre every year since the weevil came. We saw crops which this year made 475 pounds of lint to the acre, grown under physical conditions which seemed absolutely destructive 75 to 100 miles further south. We visited this portion of the parish twice-once while the cotton was still blooming (with weevils in every bloom we examined) and again after the crop was gathered, and checked each set of observations against the other. Through the courtesy of personal friends who have been planting in the parish for a number of years, we were also given access to plantation books, permitted to examine accounts of tenants, and furnished with verified statements of acreage and yields.

A brief but definite account of the methods and results on one of the plantations operated by our friends will probably answer a number of questions which are likely to present themselves to the 
Delta planter. The place in question contains 1,400 acres of cleared land. Most of it has been in cultivation many years, while there is also considerable new ground, taken in during the past two to five years. The property is traversed by a bayou which resembles Williams Bayou, near Winterville, and some parts of Deer Creek, except that most of the bank undergrowth has been cut out. There is also a typical "slough" through part of the place, heavily overgrown and with considerable moss along its banks. The land runs back from the main bayou to the woods, and the drainage is away from the bayou instead of into it. The land is dead flat throughout, and the water level is pretty close to the surface. Instead of having to use driven wells, and going 18 to 40 feet as we do, the water for cabins is supplied by shallow, dug wells, ranging from 12 to 16 feet. Practically every acre of the older land is covered with a heavy growth of cocoa, and they have to fight every kind of grass and weed which we have to contend with here. The soil is a sandy loam in places along the bayou, black but not heavy in other parts, and in some places a pretty stiff buckshot. The owner, of course, lives on the property, but the daily routine of breaking and cultivating, handling the labor, etc., is in the hands of a manager. About threefifths of the cotton acreage is worked by renters, who own their own team, but who are under just as close daily supervision as the sharehands. Before the weevil came the rent paid was a third, but this has now been reduced to a fourth.

Up to a year before the appearance of the weevil, in 1907 , about 1,100 acres out of the 1,400 were planted in cotton. The average cotton acreage to the working hand was from six to seven acres. A man and his wife renting 14 acres would usually have 12 to $12 \mathrm{I} / 2$ acres in cotton. The first step in the direction of preparing for the weevil was a reduction of the cotton acreage per hand. This meant either reducing the total cotton acreage of the place or building more houses and getting in more labor. The former plan was adopted, and the reduction was begun in 1906, the year before the weevil zDDeared. This year a total cut of approximately 200 acres was made, 
and 900 acres were put in cotton. In 1907 this was reduced to 800 acres. In 1908 it was reduced to 600 and in 1909 to 520 . Another slight cut was made in 1910 , and 480 acres put in cotton. After the appearance of the weevil they made a change in seed, bender and staple cotton being discontinued for a much more prolific varicty. The acreage and yiclds are as follows, by years:

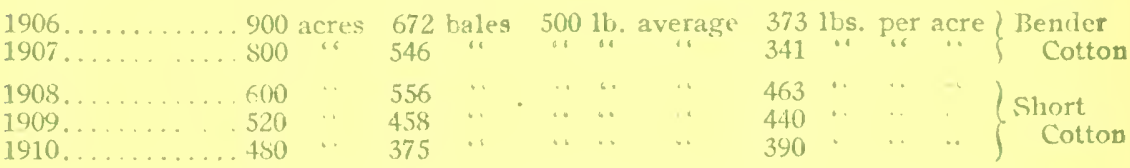

They had not finished ginning this year's crop, but an extremely conservative estimate for the 480 acres is 375 bales, or 390 pounds per acre. The crop will in fact easily run as high as 425 pounds per acre.

This is a heavier reduction in cotton acreage than we found anywhere else where we had access to exact figures. The owner of the place explained that he was influenced both by a desire to play absolutely safe and by his labor system. As he was renting practically everything, it was necessary that his tenants raise not only ample coirn for their own meal, but he wanted them to have an abundance for their stock as well. In reducing their accounts by reducing their rations, he had made every one of them raise a few hogs, and corn had to be provided for these also. The plan he adopted was to reduce the cotton acreage of each family to such an amount as could be properly handled under the new conditions-without regard to any hard and fast rule. The acreage in fact runs anywhere from $3 \frac{1}{2}$ to 6 to the hand, according to the individual family. He then made each one plant such corn as he considered necessary. This of course left the total surplus acreage on his hands, to be worked by him for wages. In his case the boll weevil problem has not been that of making cotton. Acre for acre his crop has averaged higher than before the weevil. His problem has been that of holding down the accounts of his tenants and of making profitable use of the land he has worked for wages. He solved the first proposition with satis- 
faction and with little difficulty. He issues garden seed to his tenants and his manager demands the same attention to the garden that is given to the crop. The only absolutely clean, well cultivated plantation gardens we have ever seen, we found right here. Every tenant was furnished a sow and every one raises hogs. Every encouragement is given them to raise chickens. Nearly every one now has a cow, and most of them grow a patch of cane sufficient to make their own molasses. In short, their accounts have been held down in proportion to their acreage by making them as far as possible selfsustaining. This of course was not done in a day. But the amount of stuff furnished was abruptly retuced, and the rest was accomplished gradually. All of $11 \mathrm{~s}$ who were planting in the early nineties and before know how little a negro family can live on when the general economic situation demands it. In this particular case the labor was put at once upon the old commissary, meat and bread basis-and made to realize that if anything more were wanted it must be raised at home. The problem of finding other crops for his surplus acreage has thus iar been met by planting it in corn, hay, peas, broom-corn and rice. Our friend stated that he probably would not have made such a heavy reduction in his cotton acreage had he been working on shares. In this case the tenant, having no stock to provide for, would have been made to plant more cotton and less corn. This of course is merely a question of determining just how much cotton an individual family can properly cultivate. It must be decided by each individual planter for himself, under his own knowledge of his labor supply, his already existing allotment of acreage, his particular system and methods, etc. In short, it is no more possible to establish iron-clad rules for growing cotton and handing labor under boll weevil conditions than it is for handling a plantation without boll weevils.

The object of this report is not to lay down rules and regulations, but to show bevond question that cotton is being successfully grown despite the weevil, under a great varicty of conditions of soil, climate and plantation methods. We shall point out in a concluding summary the features which seemed everywhere essential to such success. 
We saw in this parish abundant evidences of a striking diversity of opinions and practices. We talked to men who did not consider it possible to get results out of stiff land under boll weevil conditions, and with others who preferred buckshot to sandy loam. Some laid very great stress on the necessity for wide rows, while others seemed to pay no attention to the width of theirs at all. We met advocates of every variety of short staple seed of which we had ever heard, and found at least one man who was still planting long cotton on part of his place. But along one line all were agreed, and that was the necessity for avoiding a panic, for holding labor, for keeping the plantation organization intact, and for prudence and conservatism on the part of both planters and business men. And there was also one conclusion apparently universal-that after the experience of three years, cotton growing under weevil conditions was no longer an open question, but had become an accomplished fact.

\section{SUMMARY AND CONCLUSIONS.}

\section{PHYSICAL CONSIDERATIONS.}

In traveling north from the equator nature presents a transition from tropical rankness and luxuriance to the frigid barrenness of the Arctic Circle. The change from one extreme to the other is accomplished through a series of climatic and physical alterations so gradual in character that it is not possible to indicate any precise point at which one ceases and another begins. It is a steady course of shading-off processes. The most that can be done is to point out in general terms the great zones between the indefinite and intangible boundaries of which certain forms of plant life flourish and certain others cease to exist. In common parlance these have come to be described as agricultural "belts," each taking the name of the particular staple crop which constitutes the basis of its agricultural system. It is almost invariably true that more than one such crop is grown in each belt, but it is also true that some one certain staple is recognized as the characteristic product of each peculiar combination of soil and climate. Corn and cotton grow side by side in the 
Southern States, but there is no confusion of terms in designating the American cotton beit. Wheat and corn may be found together in a number of Middle and Nurthwestern States, but there is nevertheless a "corn belt" and a "wheat belt," each distinct from the other.

These are mere commonplace matters of fact-but they are of the very essence of the problem of determining the physicallimits within which a given crop may or may not be profitably grown. They cannot be ignored in any well reasoned consideration of the problem of ascertaining the region or regions in which cotton is or is not a dependable crop, whether infuenced by contingencies of soil or climate or insect pests. There is no mystery about the fact that the orange tree flourishes and furnishes both shade and fruit in the city of New Orleans, but will not grow at all in Natchez. We accept it as something entirely in the natural order of things. We know that somewhere between the two cities there is a line above which the tree will not bear, and another beyond which it will not even live. But we do not know the precise lncation of either point. We also know that somewhere between Baton Rouge and Vicksburg cane ceases to be a dependable crup, but we do not know exactly where. There is a belt through which such changes occur and in which the weather plays so important a part that each year's crop depends on each y'ear's seasons.

After a painstaking inquiry into all available sources of information on the effect of climatic and physical conditions in influencing the habits and actions of the weevil, and a careful study of local environments through a north and south stretch of some 225 miles in the alluvial lands along the Mississippi, and an east and west stretch of about 250 miles through Mississippi, Louisiana and Texas, it is our conclusion that the weevil simply adds an additional factor to those which have heretofore demanded consideration in deternining the zones of dependable cotton production. It has always been necessary to regard the factors of soil and climate, whether the crop in question were coffee, tobacco, rice, cane or cotton. And these determining factors of nature demand still closer consideration in the 
matter of even different varieties of the same crop-as between burley, perique and ordinary tobacco, or between Sea Island, alluvial and upland cotton. Can the average planter tell off-hand why he cannot grow Egyptian cotton here? Nature has already limited the belts in which certain strains of cotton may be profitably grown. The economic effect of the spread of the Mexican boll weevil is primarily that of altering to some extent the natural boundaries of such belts. Its secondary effect is that of aitering the economic conditions and methods under which the cotton producing industry has heretofore been conducted. The weevil has never yet, anywhere or at any time, rendered impossible the production of cotton. Beyond question, it has in some places rendered the growing of certain types of cotton apparenty impossible, while in very limited areas it has made unprofitable the growing of any strain of cotton which is now available. Yet even in these areas some cotton can be and actually is grown. The presence of the weevil simply means that to yrow it on a large scale in these places such a combination of favorable weather conditions is required that the extra hazard does not justify the extra effort. Such areas constitute the undlefined zones of transition betwern the dependable and non-dependable cotton belts. The problem of boll weevil cotton production, then, is no longer that of determining whether cotton can or cannot be grown. It is simplified to one of mercly determining where it may be grown to the best advantage, what varieties of cotton are best adapted to certain conditions of soil and climate, and what methods and practices will give the best and most profitable results.

11 e believe that the southern limit of dependable cotton production under a plantation system, on Mississippi alluvial soil, with any varicty of seed thus far developed, will be found to lie somewhere near a point approximately on the same east and west line as the city of Natchez. We are of the opinion that the northern limit of maximum damage by the weevil will be found to lie somewhere south of an eust and west line through Vicksburg. Between these two points it will be found possible to grow cotton profitably in years 
of favorable weather conditions, but the weatl er will be a controlling factor. (As a matter of fact, some of the very best crops made this year, in or out of the boll weevil territory, were grown in Franklin parish, south of the V. S. \& P. R. R.) Sonth of the lower line, we do not see how cotton can be safely grown in this territory on an extensive scale. North of the upper line we believe that the weevil presents no obstacle to profitable cotton growing which may not be readily overcome by the use of proper seed and proper methods.

These conclusions are not mere dogmatic opinions. They are based upon a consideration of certain tangible, even obvious, facts. The Mexiran boll weevil is a tropical insect and flourishes best and is most destructive under those conditions which furnish an environment must closely resembling that of its natural habitat. Its progress has always been most rapid in an easterly direction and slowest as it moved nortl. In studying its course and its actual destructiveness we have kept constantly before us the factors of altitude, temperature, moisture, and the physical features of the sections in which it has operated. These are considerations of nature, wholly beyond human control. They are therefore the natural controlling factors. We may here disregard economic considerations entircly-as being sufficiently artificial to be shaped by human agencies. If natural conditions make it impossible to grow cotton, then the situation is beyond the remedy of man's activities. If, on the other hand, the natural factors do not themselves render cotton growing impossible, the economic factors may be made to conform to the necessities of the situation and success beromes merely a matter of intelligent human effort.

We have before us the climatological summaries for Louisiana, Texas, Arkansas and Mississippi. Studying them before and after a personal examination of the individual localities in which we are interested, it is easy to see how misleading this weather data may be, and how liable to misinterpretation. Two to three degrees will cover the difference of average temperature, for example, between Avoyelles and Madison Parishes. Two to three inches will cover the difference of rainfall. The points of observation in the two parishe $\mathrm{s}_{\mathrm{S}}$ 
are probably ninety miles apart. These recorded differences of weather, in favor of the more northerly parish, do not in themselves account for the very great difference of relative weevil damage between the two places. The reai difference is a physical one, expressed in the differences of vegetation, dew moisture, soil conditions, etc., which are the accumulated product of centuries of really insignificant annual differences of temperature and rainfall. The same temperature in any given winter may have very different relative effects on the weevil in the two parishes. Winter survivals of weevils are influenced by the character of hibernating quarters afforded by given localities, as well as by actual temperatıre itself. The number of weevils surviving the winter constitutes a factor of the utmost importance in its effect upon the crop. With these considerations in mind, the great difference between the ravages of the weevil in the two parishes of Avoyelles and Madison is readily understood when one has examined the physical conditions of the two-thougli it is not at all explained by the bare figures of a weather report. W'hile the factor of temperature is one of the most important in the entire boll weevil problem, we wish to emphasize the fact that the effect of a given temperature on the weevil in both winter and summer is determined by physical considerations. We have in Washington county the advantage of probably one degree of temperature over the general Madison parish territory. The nearest point to that parish for which the figures of rainfall are available is Vicksburg, just across the river. The annual precipitation there is 53.74 inches, as against only 47.75 inches at Greenville, a difference of practically six inches in favor of this territory. But just as such figures do not disclose the real difference between Avoyelles and Madison parishes so they do not tell the whole story as between Madison parish and Washington county. After a careful study of every physical factor in the large area covered by our investigations, we are satisfied that as regards such physical considerations this county is as favorably situated as any of which we have any knowledge. This statement may of course be subject to modification by conditions in individual 
localities, but we believe it to be sound as applied to this county and section as a whole. As between a plantation which is thoroughly drained, free of sloughs, where the cultivated land lies in a large open block, where the ditch banks and roads are kept clean, where tongues of timber do not project into the fields, and one in which contrary cunditions exist, there is of course a great advantage with the former place. But these physical disadvantages may usually be remedied, and it will certainly pay to remove them as far as possible. The only sections we saw which possess any apparent advantage over ours are certain areas of prairie land in Texas. But upon investigation these are usually found to be areas of deficient rainfall.

Another factor to be considered is that of soil. We found a great variety of opinion on this point. Some planters insisted that cotton could not be grown on buckshot land, while others clained that there was no difference between it and lighter soil, as far as boll weevil conditions are concerned. Out of this general confusion of views we extracted the conclusion that this is a matter of local condition. There is certainly an advantage of "quick" over "slow" land, and every planter knows the cuts on his property on which cotton grows off most slowly in the spring.

We found but one opinion as to the matter of drainage. It was everywhere agreed that drainage as nearly perfect as possible is an absolute necessity. But we do not need the boll weevil to tell us this.

The matter of the proper width of rows comes also under the head of the physical considerations which affect the yield under boll weevil conditions. We found rows all the way from three feet apart in portions of Texas to five and a half, and even six, feet in Madison parish, Louisiana. The consideration governing the width is that of the necessity of giving the cotton such space as will give a maximum amount of sun to the roots of the stalks, with a view to forcing the growth as much as possible-at the same time drying out the middles so as to give the quickest possible opportunity for cultivating after a rain. It is manifest that the width necessary to accomplish these ends will depend on the nature of the soil and the 
character of growth of the particular variety of cotton planted. On a poor, light soil, such as the chalk-colored prairie land of parts of Texas, where cotton grows to a height of about three feet. rows only three feet apart are amply sufficient. On the alluvial lands of Madison parish a much wider row is necessary. What impressed us as being the safest rule which we observed anywhere was that of spacing the rows so as to prevent the cotton from doing more than barely locking in the middles. This of course varies according to soil and cotton.

\section{ECONOMIC CONSIDERATIONS.}

In submitting our observations on the economic aspects of the boll weevil problem, we are prompted more by a desire to make this report as complete as possible than by any such idea as that of telling planters, bankers or factors how to handle their respective lines of business. But for the fact that we have heen asked a number of questions which fall properily under the above caption, we would have nothing whatever to sav. along this line.

After what we have already written, it seems unnecessary to add anything on the subject of the danger of business and labor panics. We did not talk to a planter who failed to dwell on the fact that his damage was in proportion to his ability to hold and take care of his labor pending such readjustment as it was necessary for him to make. And his success or failure in this effort, where he was not financially independent, depended on the degree of co-operation between himself and his banker or factor. We also talked to a few business men who frankly admitted that they themselves shared the responsibility for having killed the goose that was laying the golden egg. In the light of the recovery which everywhere followed the panic (always excepting of course the territory below the line of boll weevil cotton production), practically every business man with whom we talked agreed that a different policy on the appearance of the weevil would in all probability have prevented even such distress as at first occurred. 
Of one thing we may assure ourselves; while we are unquestionably above the line of maximum boll weevil damage, we are well within the region of panics. We cannot make cotton without labor, and we cannot hold our labor if we pursue the suicidal policy of not only becoming frightened ourselves, but of showing our fright to our negroes. We may depend upon it that our conduct, whatever it may be, will be reflected in that of onr labor. And the labor cannot live unless it is fed. If we do as a good many planters in Louisiana did-throw up our hands and tell our negroes that we can no longer take care of them, it will not take them as long to find other homes as it will take us to find other labor. The boll weevil cannot put this country out of business, but we can easily be bankrupted by our own folly.

This does not mean that the approaching situation does not require either prudence or conservatism. On the contrary, it demands a high degree of each. It is notorious that under the influence of high prices there is always more or less of wildcat business done in every cotton country. Both negroes and white men are given lines of credit to which they are not entitled by any consideration of moral responsibility or business capacity. The boll weevil will eliminate this class of business. Unquestionably it should also put a stop to ill considered expansions in planting and all other lines of business. It will be necessary for the planter to furnish his labor on a basis of "living" rations alone.-and let the negro learn to supplement this with what may le growin at home. The financial demands of the country upon the town should be reduced to the basis of expenditures absolutely required for the continued production of the crop upon which the welfare of the community as a whole depends. The assistance of the town to the country should be rendered in such measure as may be necessary to conserve interests which should be recognized as mutual. This is a cotton country, and the cotton growing inclustry is absolutely the basis of the business life of the community. Its destruction inevitably involves the paralysis of every other form of enterprise. Its maintenance is therefore a matter of community concern. 
In saying that this is a cotton country, we are not unmindful of the suggestions as to diversification which constitute an important feature of the advice usually given the cotton planter about to be attacked by the weevil. But we had impressed upon us a hundred times the danger of carrying the diversification idea too far in a staple crop country. The men whom we found everywhere to be most successful were those who for a mainstay had stuck to the crop which they were accustomed to grow. We have not one word to say against a carefully considered plan of diversified crops. But we believe the extent to which it is undertaken should be governed by the amount of surplus land which the planter has left on his hands as a result of reducing his cotton acreage to such proportions as can be properly handled by the labor at his command, and by the amount of land he may have which for any reason may be unsuited to cotton under boll weevil conditions.

As to the methods of cultivation required under the new order of things, it is unnecessary for 11 to say anything here. A letter addressed to Dr. S. A. Knapp, Department of Agriculture, Washington, will bring bulletins containing all the information desired along this line. And we may add here that the most successful boll weevil planters we met were the most ontspoken in their endorsement of Dr. Knapp's assistance and advice. He has been a prop to many communities in allaying labor and business panics, and his efforts deserve the highest praise. We found some diversity of opinion as to the efficacy of stalk destruction as a means of diminishing the number of weevils surviving the winter, but many planters unhesitatingly advocated it. There was practical unanimity as to the necessity of picking up and burning infested squares.

As to the matter of the best variety of cotton to plant we found numberless opinions. In Texas we heard Triumph endorsed on every hand. In Louisiana, on the alluvial lands of both the Red and Mississippi rivers, we found a marked preference for a cotton with smaller leaves and less foliage. Here the choice lay between such small boll varieties as King, Simpkins, Sugar Loaf, etc. We found some 
staple cotton still being grown in one or two Texas connties which are in our latitude, and in one place in Louisiana to the south of us. We may be far enough north to grow staples successfully, but that remains to be proved. Personally, for the first year or so, until we have had opportunity to test the matter, we think the safer policy would be to plant a shorter, more prolific and quicker cotton than any of the staples of which we now have any knowledge.

A moment's reflection by those who have been interested in growing cotton for the past fifteen to twenty years, either as planters, tankers or factors, should dissipate the bugaboo aspects of the boll weevil problem. Except in the few places in Louisiana and Mississippi where the cotton growing industry has been actually destroyed,places from whose experience we have absolutely nothing to fear,the wcevil has nowhere created a condition anything like as bad as some which all of us have successfully weathered in the past. From a personal inspection of actual figures of cotton production, and irom a careful personal examination of cotton fields, we are prepared to say that every well-managed plantation which we visited has an average annual cotton production, under boll weevil conditions. ranging from 240 to 400 pounds of lint per acre. The yield varied with ronditions entirely apart from boll weevil considerations,--such for example as labor, soil, drainage, weather, etc. In every instance it was more influenced by individual methods of management than by anything else. Wie need only recall the figures taken from the books of a Madison parish planter to illustrate the possibilities under propes management and clnse supervision, on a thoroughly organized plantation. The yield here has averaged more than 425 pounds of lint to the acre during the three boll weevil years of 1908,1909 and 19io. How many Delta planters can equal this during these same three years?

It will of conrse be said at once that this was accomplished by planting a shorter cotton than any Delta planter wants to adopt. This i: true, but granting that we find it impossible to grow staples here, common sense should furnish its own reply to such a proposi- 
tion. This cotton has sold at prices ranging from 12 to 15 cents for the past two years. If we reduce the yield to 325 pounds of lint. or even to 300 pounds, and reduce the price to ten cents, we still have a better state of affairs than all of us experienced when staple cotton was selling for six or seven cents a pound. How many planters here would throw up their hands, abandon their labor and land and quit the business, if they knew with absolute certainty that within two years staple cotton would be back to the same level of prices which obtained from 1894 to 1898 ? The number could be connted on the fingers of one hand. And yet, if we only stick to the facts and eliminate the single factor of panic, we cannot by any amount of human ingenuity twist as disastrous a set of conditions out of the boll weevil proposition as would be presented by such a decline in price. We would in the latter case simply cut the garment according to the cloth, - and that is the sum and substance of the economic readjustment rendered necessary by the weevil. It is the beginning and the end of the solution of the whole boll weevil problem. Its accomplishment will be rendered difficult or easy according to whether we allow ourselves to be driven into the fight in a state of demoralization and disorder, or accept the situation in time, meet it as we would any other business problem, and work it sut from the beginning with prudence, energy and common sense.

We wish to make public acknowledgement of our obligation to the many gentlemen who aided us on our trip, and to express our renuine appreciation of the unfailing courtesy and generous spirit of helpfulness which characterized their discussions with us. We wish also to thank Mr. Bolton Smith, of Memplis, and Dr. S. A. Knapp, of Washington, for ietters of introduction which very greatly facilitated our investigations.

ALFRED H. STONE. JULIAN H. FOR'T.

Dunleith Plantations, Dunleith. Washington County, Miss., December 15, 1910. 
One copy del. to Cat. Div.

SAP ST 1519 
An 27 133 







\section{LIBRARY OF CONGRESS

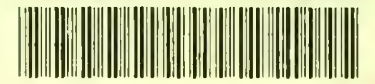 0000888476A}

